doi:10.4149/neo_2016_005

\title{
In vitro and in vivo antitumor activity of a novel chlorin derivative for photodynamic therapy
}

\author{
C. Y. ZHANG ${ }^{1}$, L. J. ZHANG ${ }^{1}$, J. W. $\mathrm{LI}^{2}$, J. H. LI' ${ }^{2}$, Z. M. WU' ${ }^{2}$, L. X. ZHANG ${ }^{3}$, N. CHEN ${ }^{3}$, Y. J. YAN ${ }^{3}$, Z. L. CHEN \\ ${ }^{1}$ Department of Pharmaceutical Science \& Technology, College of Chemistry and Biology, Donghua University, Shanghai 201620, P. R. China; \\ ${ }^{2} Y i w u$ City Central Hospital, Zhejiang 322000, P. R. China; ${ }^{3}$ Shanghai Xianhui Pharmaceutical Co. Ltd, Shanghai, 200433, China
}

*Correspondence: zlchen1967@yahoo.com

Received April 20, 2015 / Accepted August 10, 2015

\begin{abstract}
In presented paper, a new chlorin derivative 5,10,15,20-tetrakis[(5-N-morpholino)pentyl] chlorin (TMC) was investigated as a photosensitizer in photodynamic therapy (PDT). Cellular uptake, cytotoxicity, intracellular location, biodistribution and antitumor effects were studied using human esophageal cancer cells (Eca-109) and human cervical cancer cells (Hela) in vitro and an esophageal cancer model in BALB/c nude mice. Cellular uptake and biodistribution of TMC were measured by fluorescence spectrophotometer. Cytotoxicity of TMC against Eca-109 and Hela cells was determined by MTT assay. The intracellular location of TMC was detected with a confocal microscopy. It was showed that TMC could rapidly accumulate in tumor cells and localize in cytoplasm. TMC was found to be low-toxic in dark but extensively photosensitive in vitro. A fast clearance rate of TMC was observed in Eca-109-bearing mice. In particular, TMC could significantly inhibit the tumor growth and exhibit a notable antitumor efficacy for PDT in vivo.
\end{abstract}

Key words: photodynamic therapy, photosensitizer, tumor, chlorin

Photodynamic therapy (PDT) has emerged as a promising tool for treating diseases characterized by unwanted cells or hyperproliferating tissues [1]. PDT utilizes a photosensitizer (PS) in the presence of $\mathrm{O}_{2}$ and light to selectively destroy cancer cells by generating reactive oxygen species (ROS), which has a strong cytocidal effect through photochemical reactions[2-5]. PDT has potential advantage compared with other general treatment such as surgery, chemotherapy and radiation therapy for its tumor targeting and few side effects.

Most of photosensitizers (PSs) have low selectivity for cancer cells and induce long-term skin photosensitivity as a major side effect. The absorption of an ideal PS should oc-

\footnotetext{
Abbreviations: TMC - 5,10,15,20-tetrakis[(5-N-morpholino)pentyl] chlorin; PDT: photodynamic therapy ROS - reactive oxygen species; ${ }^{1} \mathrm{O}^{2}$ - singlet oxygen; DPBF - 1, 3-diphenylisobenzofuran; DMSO - dimethyl sulfoxide DMF: N, N-dimethylformamide; PBS - phosphate buffered saline FBS - fetal bovine serum; Hela cell - human cervical cancer cell line; Eca-109 cell - Human esophageal cancer cell line; MTT - 3-(4, 5-dimethyl2-thiazolyl)-2, 5-diphenyl-2H -tetrazolium bromide
}

cur in the deep red and near infrared portion of the visible spectral. Consequently, significant efforts have focused on the synthesis of new PSs which are efficiently excited by light at the optimal wavelength range for tissue penetration and have high selectivity for cancer cells [6].

In recent years, chlorin-based PSs are receiving considerable attention, which have been found as phototoxic drugs for PDT [7, 8]. They often have high singlet oxygen quantum yield and a narrow but very strong Q-band around $650 \mathrm{~nm}[9,10]$. Such an inherent long wavelength characteristic provides more efficient light penetration in tumor tissues as compared to those PSs absorbing light at short wavelength $[11,12]$.

In the current study, we investigated the photodynamic activity of a novel chlorin derivative 5,10,15,20-tetrakis[(5$\mathrm{N}$-morpholino)pentyl] chlorine (TMC) (Fig. 1), both in vitro and in vivo. The photophysical property was measured. To further elucidate the cellular mechanism of action, the intracellular localization of TMC was detected. The accumulation and distribution of TMC in the tumor and the normal tissues were also tested. 


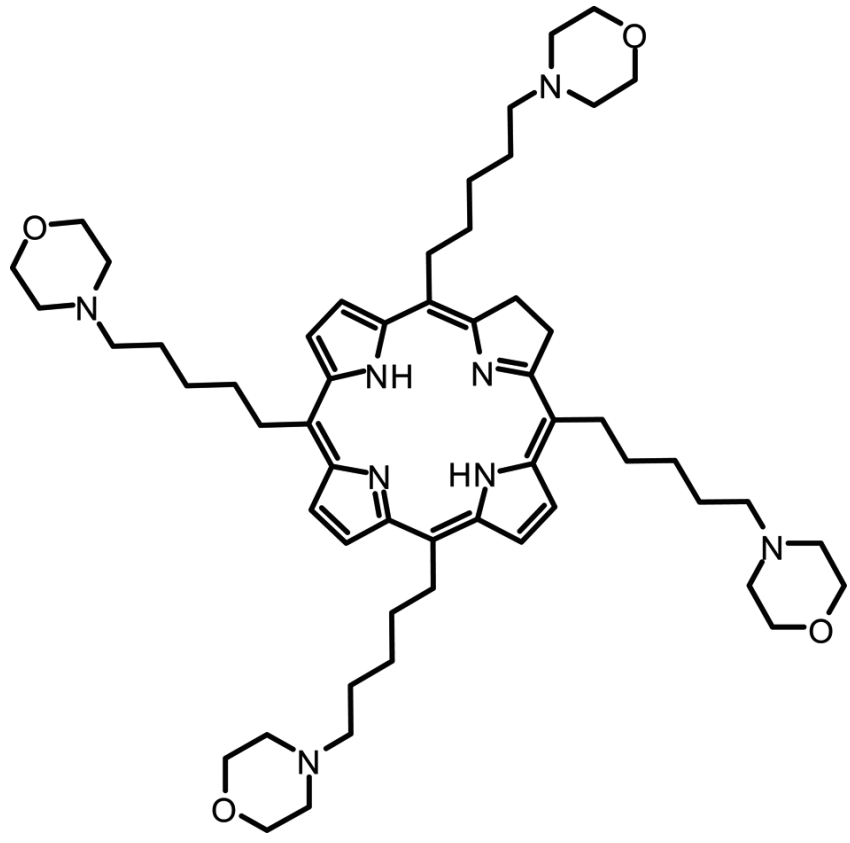

Figure 1. Chemical structure of TMC.

\section{Materials and methods}

Materials. TMC was synthesized in our laboratory and the patent has been applied. 1, 3-diphenylisobenzofuran (DBPF), dimethyl sulfoxide (DMSO) and N, N-dimethylfor-mamide (DMF) were obtained from Sinopharm Chemical Reagent Co., Ltd. All the chemicals and reagents were of analytical grade and used without any purification.

Absorption and emission spectra. UV-Vis absorption spectrum was recorded on an ultraviolet-visible spectrophotometer (Model V-530, Japan). Fluorescence spectra were measured on a fluorescence spectrometer (FluoroMax-4, France). Slits were kept narrow to $1 \mathrm{~nm}$ in excitation and 1 or $2 \mathrm{~nm}$ in emission. Right angle detection was used. All the measurements were taken at room temperature in quartz cuvettes with path length of $1 \mathrm{~cm}$. TMC was dissolved in DMF to get $5 \mu \mathrm{M}$ solution.

Quantum yield for singlet oxygen generation. The quantum yield of singlet oxygen $\left({ }^{1} \mathrm{O}_{2}\right)$ generation by TMC upon photoexcitation was determined by decomposition of DPBF in DMF. The singlet oxygen quantum yield was correlated to the decay of the absorption of DPBF at $410 \mathrm{~nm}$ [13]. Typically, DPBF and TMC were dissolved in DMF. $2 \mathrm{~mL}$ DMF solution containing $20 \mu \mathrm{M}$ DPBF and $0.5 \mu \mathrm{M}$ TMC was placed in a quartz cuvette of $1 \mathrm{~cm}$ optical path and irradiated with 650 $\mathrm{nm}$ light for different periods of time at room temperature. The power density was $5 \mathrm{~mW} / \mathrm{cm}^{2}$. Nd: YAG laser was used as the light source. The absorption spectra were measured at different periods of time with an UV-Vis spectrophotometer. The first-order rate constant of the photo-oxidation of DPBF by
${ }^{1} \mathrm{O}_{2}$ was obtained by plotting $\mathrm{Ln}[\mathrm{DPBF}]_{0} /[\mathrm{DPBF}]_{\mathrm{t}}$ as a function of the irradiation time, where $[\mathrm{DPBF}]_{0}$ and $[\mathrm{DPBF}]_{\mathrm{t}}$ represent absorbance at time 0 and at time $t$, respectively [13]. The rate constant was converted into ${ }^{1} \mathrm{O}_{2}$ quantum yield by comparison with the rate constant for DPBF photo-oxidation sensitized by methylene blue, for which ${ }^{1} \mathrm{O}_{2}$ quantum yield was shown to be $0.49[9,14]$.

Cell lines and cell culture. Human esophageal cancer cell line (Eca-109 cell) and human cervical cancer cell line (Hela cell) were obtained from Shanghai Institute of Cell Bank, Chinese Academy of Sciences. Eca-109 cells were cultured in RPMI-1640 medium and Hela cells were cultured in DMEM medium. All the media were supplemented with $10 \%$ fetal bovine serum (FBS), 50 units/mL penicillin, and 50 units $/ \mathrm{mL}$ streptomycin. All cell culture related reagents were purchased from Shanghai Ming Rong Bio-Science Technology Co., Ltd. Cells were incubated at $37^{\circ} \mathrm{C}$ in $5 \% \mathrm{CO}_{2}$ in a humidified incubator.

Cellular uptake of TMC. Eca-109 cells and Hela cells were respectively seeded in 24 -well cell culture plates $\left(1 \times 10^{6}\right.$ cells per well) and approximately $24 \mathrm{~h}$ later the cells were washed twice with phosphate buffered saline (PBS). The cells were then incubated with $5 \mu \mathrm{M}$ TMC in culture medium during a time lapse of $0.5,1,2,4,6,8,10,12,24 \mathrm{~h}$ at $37^{\circ} \mathrm{C}$ in dark. After incubation, the cells were washed twice with PBS and solubilized in $200 \mu \mathrm{L} /$ well DMSO. The intracellular concentration of TMC was fluorometrically determined with excitation/ emission wavelengths of 412 and $646 \mathrm{~nm}$ using a fluorescence spectrophotometer. The concentration of TMC was calculated using standard curves generated with various known concentrations of TMC. Then the kinetics of uptake (concentration of drug $/ 10^{6}$ cells vs time) was performed.

Cytotoxicity of TMC. Eca-109 cells and Hela cells suspension were respectively seeded in 96-well plates $\left(1 \times 10^{4}\right.$ cells per well) and incubated under $5 \% \mathrm{CO}_{2}$ at $37^{\circ} \mathrm{C}$. After $24 \mathrm{~h}$ the TMC were added at different concentrations $(1,2,4,8$, $16 \mu \mathrm{M})$. The cells without TMC served as control. Phototoxicity of TMC was evaluated at $12 \mathrm{~h}$ of incubation (irradiation with Nd: YAG laser at $650 \mathrm{~nm}$, power density $25 \mathrm{~mW} / \mathrm{cm}^{2}$ ). The culture medium with TMC was removed and the cells were washed twice with PBS before irradiation with different light doses $\left(4,8,12 \mathrm{~J} / \mathrm{cm}^{2}\right)$. After irradiation the cells were incubated in dark for $24 \mathrm{~h}$. Dark toxicity was carried out under the same conditions without irradiation in parallel. The cell viability was evaluated by the 3-(4, 5-dimethyl-2-thiazolyl)-2, 5-diphenyl-2H-tetrazolium bromide (MTT, Sigma Chemical Co., St. Louis, USA) colorimetric assay [15]. The absorbance at $570 \mathrm{~nm}$ was measured using a microplate reader (Bio-Rad, CA, USA).

Intracellular localization of TMC. Eca-109 cells were seeded on coverslips in 6 -wells plates $\left(5 \times 10^{4}\right.$ cells per well $)$ and incubated with $5 \mu \mathrm{M}$ TMC in dark at $37^{\circ} \mathrm{C}$ for $4 \mathrm{~h}$. The culture medium with TMC was removed and the cells were washed with PBS. The cells were then observed with a confocal microscopy (Carl Zeiss LSM 700, Jena, Germany). The TMC 
fluorescence was detected at $412 \mathrm{~nm}$ excitation and $646 \mathrm{~nm}$ emission.

\section{In vivo experiments}

Animal models. Male BALB/c nude mice (5 weeks old) were injected subcutaneously with $200 \mu \mathrm{L}$ of a suspension of Eca- 109 cells $\left(5 \times 10^{6}\right.$ cells $\left./ \mathrm{mL}\right)$ into posterior limbs. When implanted tumor sizes were more than $1 \mathrm{~cm}$ in diameter, tumors were excised and small pieces of the tumor (approximately $2 \mathrm{~mm}^{2}$ pieces) were implanted subcutaneously into the right anterior limb of male BALB/c nude mice (5 weeks old). When tumor sizes had reached 6-7 $\mathrm{mm}$ in diameter after implantation, the BALB/c nude mice were used for studies of biodistribution and PDT efficacy of TMC.

Biodistribution of TMC. The biodistribution and clearance of TMC was investigated in Eca-109 tumor-bearing nude mice using fluorescence measurements. TMC (20 mg/kg) was injected intravenously into tumor-bearing nude mice. Nine tissues samples from tumor-bearing mice were analyzed at the indicated times after injection. These samples included heart, liver, spleen, lung, kidney, muscle, skin, brain and tumor. Mice were sacrificed and tissue samples were collected at 1, 3, 6, 12 and $24 \mathrm{~h}$ (five mice per time). The samples were stored at $-80{ }^{\circ} \mathrm{C}$ until analysis. The wet weight of each tissue was $100 \mathrm{mg}$, and the tissue samples were mixed with ultrapure water (100 mg wet tissue $/ 5 \mathrm{~mL}$ ultrapure water). The tissue samples were homogenized, and then centrifuged at $10000 \mathrm{rpm}$ for $5 \mathrm{~min}$ at $4{ }^{\circ} \mathrm{C}$. The supernatants were collected. Fluorescence in the supernatants was measured with a fluorescence spectrophotometer at $646 \mathrm{~nm}$, and the excitation wavelength was $412 \mathrm{~nm}$. Concentrations of TMC in the tissue samples were calculated from standard concentration curves constructed by measuring the fluorescence of several different known concentrations of TMC.

PDT efficacy of TMC on Eca-109 tumor-bearing nude mice. TMC (5 mg/kg) was injected into Eca-109 tumor-bearing nude mice $(n=5)$ via tail vein. The nude mice were randomly
A.

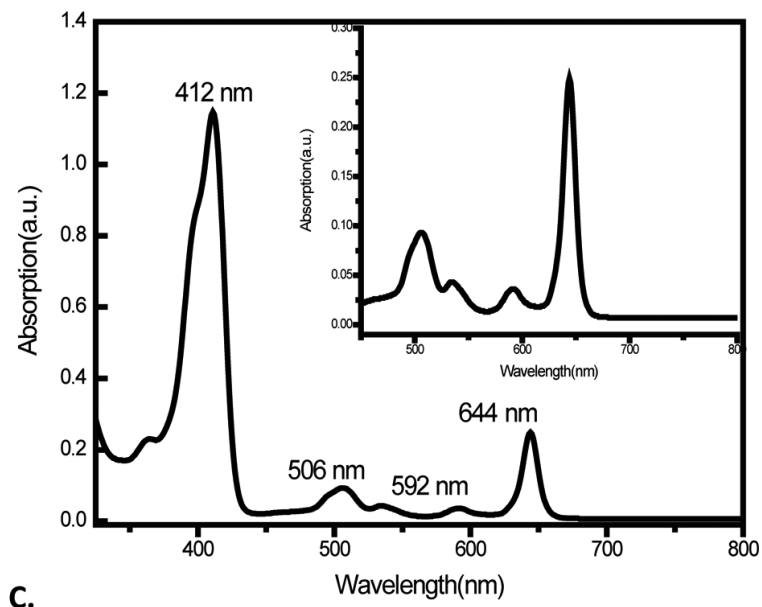

C.

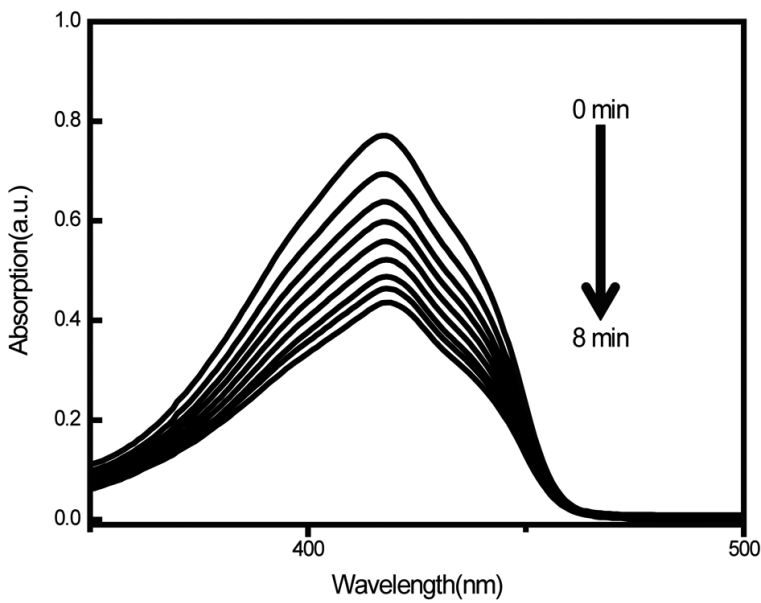

B.
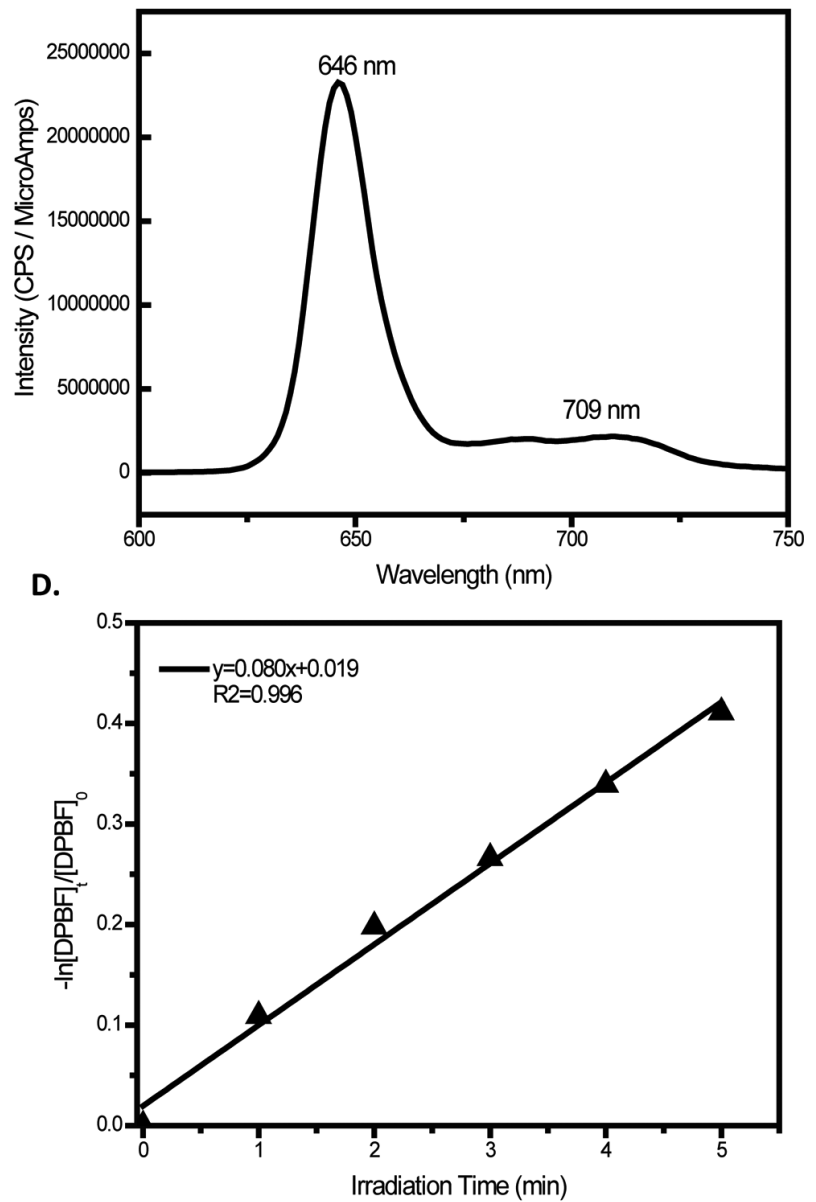

Figure 2. The spectrum and singlet oxygen quantum yield of TMC. A. UV-Vis absorption spectrum of TMC in DMF at $5 \mu$ M. B. Emission spectrum of TMC, which was excited at $412 \mathrm{~nm}$, and its peaks were at $646 \mathrm{~nm}$ and $709 \mathrm{~nm}$. C. Photodecomposition of DPBF by ${ }^{1} \mathrm{O}_{2}$ after irradiation of TMC in DMF. D. First-order plots for the photodecomposition of DPBF photosensitized by TMC. 

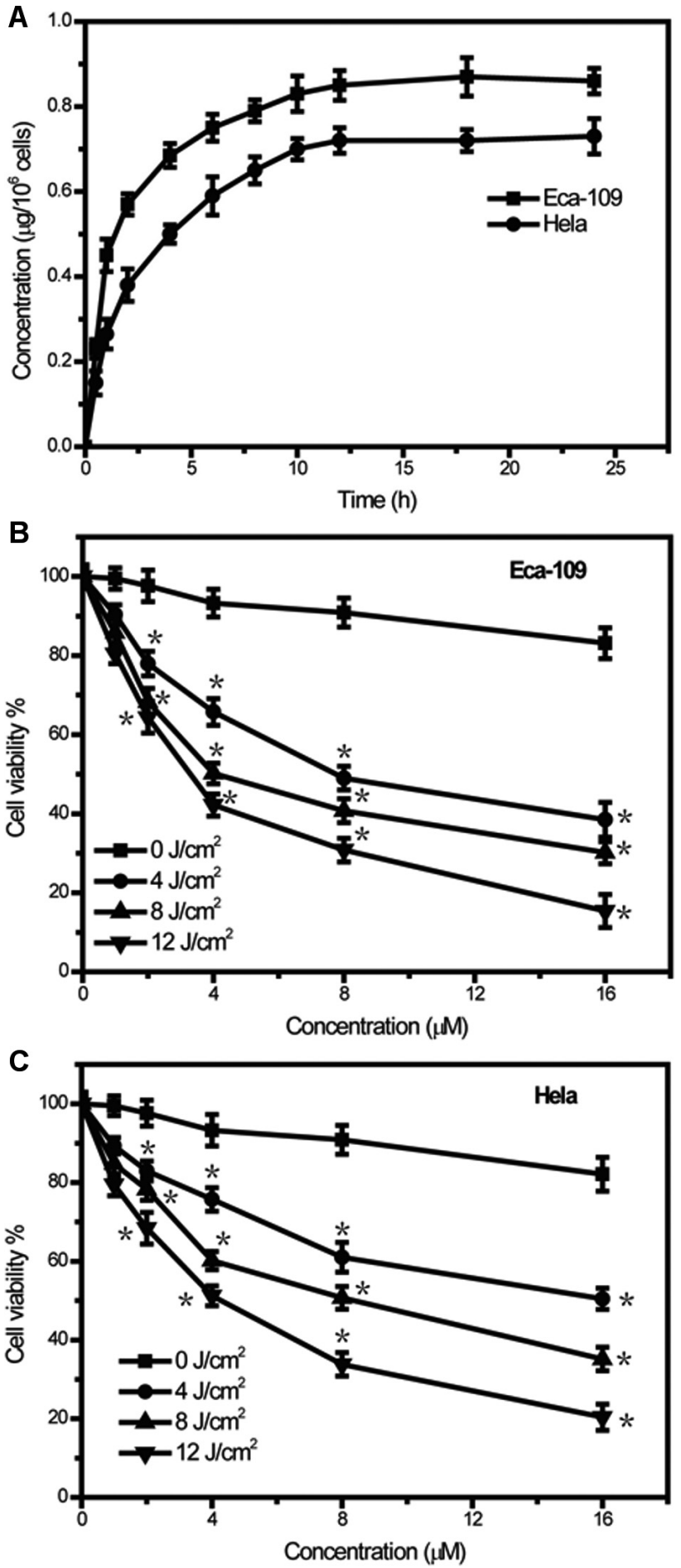

Figure 3. Cellular uptake and cytotoxicity of TMC on Eca-109 and Hela cells. A. TMC uptake in Eca-109 and Hela cells as a function of incubation time. The concentration of TMC was determined by fluorescence analysis. B. Cytotoxicity of TMC on Eca-109 cells. C. Cytotoxicity of TMC on Hela cells. All data represent mean \pm SD $(n=3)$. ${ }^{\star}$ indicates difference at the p $<0.05$ significance level. Dark toxicity $\left(0 \mathrm{~J} / \mathrm{cm}^{2}\right)$ of TMC was assessed with different concentrations (range from 1 to $16 \mu \mathrm{M}$ ). Phototoxicity was assessed with different light doses $\left(4,8,12 \mathrm{~J} / \mathrm{cm}^{2}\right)$ and different concentrations (range from 1 to $16 \mu \mathrm{M}$ ). divided into three groups: control, light irradiation only and PDT. Nude mice were irradiated at the tumor site using laser light $\left(650 \mathrm{~nm}, 100 \mathrm{~J} / \mathrm{cm}^{2}, 180 \mathrm{~mW} / \mathrm{cm}^{2}\right)$ at $3 \mathrm{~h}$ after administration. The therapeutic efficacy was evaluated by monitoring tumor growth every day. Tumor dimensions were measured with a caliper, and tumor volume $\left(\mathrm{mm}^{3}\right)$ was calculated as (longer diameter $) \times(\text { shorter diameter })^{2} \times 1 / 2$ [16]. The difference in tumor volume between different groups was analyzed by student's $t$ test using the SPSS16.0 software.

The experiments were carried out in accordance with the guidelines issued by the Ethical Committee of Donghua University.

\section{Results}

UV-Vis absorption and emission spectrum. UV-Vis and fluorescence spectra of TMC in DMF are shown in Fig. 2. The absorption peak of TMC is at $412 \mathrm{~nm}$ and it also has absorption at 506, 592, $644 \mathrm{~nm}$ (Fig. 2A). TMC showed an intense fluorescence band at $646 \mathrm{~nm}$ upon excitation at 412 nm (Fig. 2B).

Singlet oxygen quantum yield. The most common mechanism of action of the photosensitizers used in PDT (type II mechanism) involves the production of ${ }^{1} \mathrm{O}$, upon photo-excitation [17], so ${ }^{1} \mathrm{O}_{2}$ quantum yield is one of the most important parameters indicating efficacy of photosensitizers for PDT. The ${ }^{1} \mathrm{O}_{2}$ quantum yield of TMC was 0.41 (Fig. 2C, D).

Cellular uptake of TMC. TMC uptake in Eca-109 and Hela cells were evaluated using a concentration of $5 \mu \mathrm{M}$ at different incubation times. In Fig. 3A, TMC was rapidly incorporated in Eca-109 and Hela cells in the initial time $(<6 \mathrm{~h})$ and reached a plateau value after $12 \mathrm{~h}$.

Phototoxicity and cytotoxicity of TMC. PS toxicity is a very important property that determines its therapeutic use, the cytotoxicity of TMC was investigated on Eca-109 and Hela cells at different concentrations and light doses. As shown in Fig. 3B, C, TMC exhibited low dark toxicity after $12 \mathrm{~h}$ incubation with Eca-109 and Hela cells. When the concentration was less than $4 \mu \mathrm{M}$, TMC did not show any appreciable toxicity on cells. Cell viability decreased when the PS concentration or/ and the light dose were raised. No toxicity was noticed upon exposure of Eca-109 and Hela cells to light alone without TMC (Data not given).

Intracellular localization. The intracellular location of the PS is of special significance to photodynamic efficacy, it determines the site of primary photodamages and the type of cellular response to the therapy [18]. The intracellular localization of TMC was evaluated by confocal microscopy upon exposure of Eca-109 cells to TMC $(5 \mu \mathrm{M})$ for $4 \mathrm{~h}$. TMC was mainly distributed in cytoplasm and nuclear membranes as shown in Fig. 4.

Biodistribution of TMC. Fig. 5 shows the distribution of TMC in Eca-109 tumor-bearing mice tissues for time periods ranging from 1 to $24 \mathrm{~h}$ after intravenous injection of $20 \mathrm{mg} /$ $\mathrm{kg}$ of TMC. The maximum concentration of TMC in tumor 


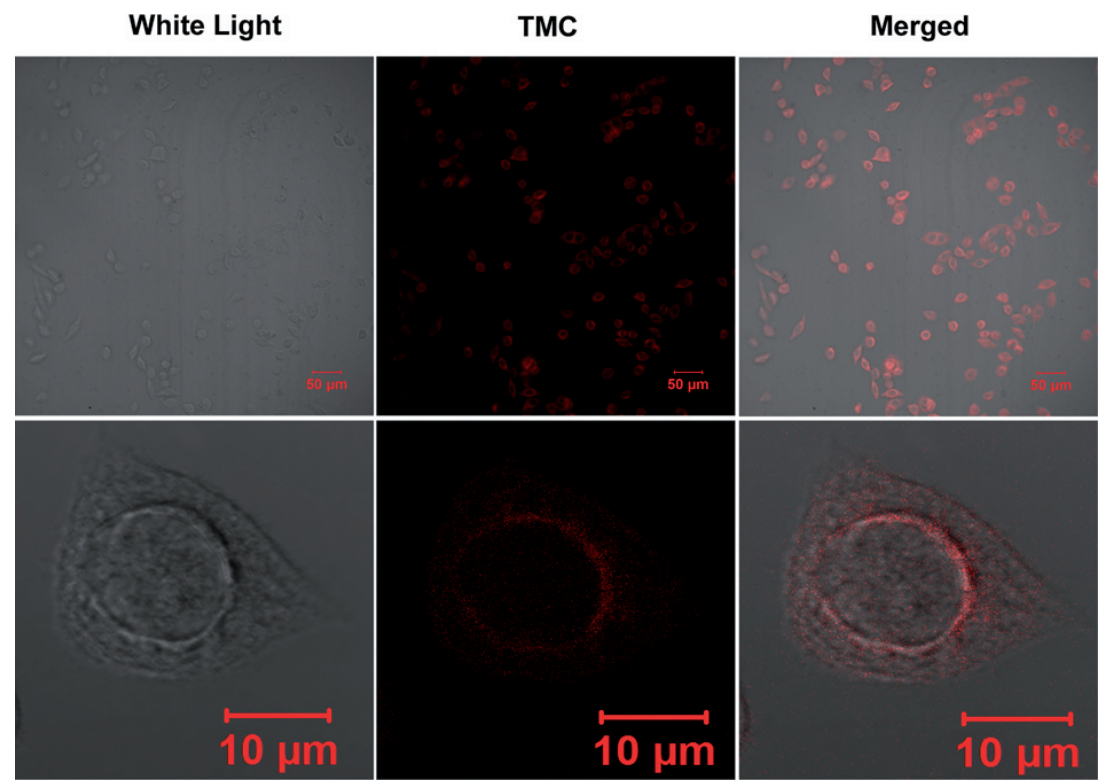

Figure 4. Intracellular location of $5 \mu$ M TMC in Eca-109 cells after $4 \mathrm{~h}$ incubation. The red fluorescence signal of TMC was detected at $412 \mathrm{~nm}$ excitation and $646 \mathrm{~nm}$ emission with a confocal microscopy.

tissue occurred at $1 \mathrm{~h}$ after administration. In tumor tissue, the accumulation of TMC was 1.6 times of that in skin at 3 $\mathrm{h}$ after injection, and the clearance of TMC in other tissues was superior to that in tumor tissue. At $12 \mathrm{~h}$ after administration, TMC was only slightly detected in normal tissues except for liver and kidney. TMC had been almost completely discharged from all tissues at $24 \mathrm{~h}$ after administration.

PDT efficacy of TMC on Eca-109 tumor-bearing nude mice. Compared with the control group, there was a clear injury in the tumor sites of mice treated with PDT one day after irradiation. PDT-treated tumors began to shrink within 3 days and became dark, hardened and dried over the course of the next 6 days, eventually formed a scab by 12 days after treatment (Fig. 6B). The damage of tumor induced by light irradiation was not observed in the light irradiation group. There was no significant difference in tumor volume between the control group and the light irradiation group $(\mathrm{p}>0.05)$. As shown in Fig. 6A, the tumor volume in control or light irradiation group continued to increase and was significantly larger than that in PDT group 6 days after treatment $(\mathrm{p}<0.01)$.

\section{Discussion}

PDT consists of three important agents: light, $\mathrm{O}_{2}$ and PS. PS is unequivocally the most important of the three. An ideal photosensitizer should have absorption spectra at long wavelengths, which allows deeper tissue penetration and decreases non-specific lesions [19]. Red light (600-800 nm) corresponding to deep tissue penetration is desirable for biomedical application and is known as the optical window [1]. TMC shows high absorption in the long-wave region of the

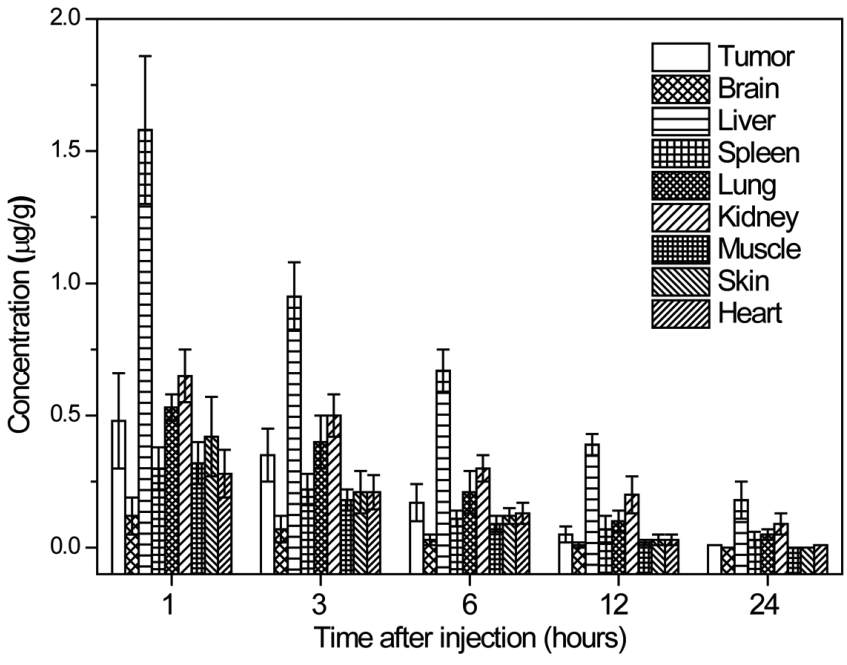

Figure 5. TMC biodistribution after intravenous injection $(5 \mathrm{mg} / \mathrm{kg})$ in Eca-109 tumor-bearing mice at different times. Nine tissues from tumor-bearing mice were analyzed at the indicated times after injection. Concentration of TMC in the tissue was determined using fluorescence measurements. All data represent mean $\pm \mathrm{SD}(n=5)$.

visible spectrum (644 nm), which allows for deeper penetration of light through tissue and gets better therapeutic effect. For most PDT photosensitizers, it has been demonstrated that generation of ${ }^{1} \mathrm{O}_{2}$ is responsible for the initiation of cell death $[20,21]$ and TMC shows a singlet oxygen quantum yield of 0.41 .

In vitro, TMC could rapidly accumulate in tumor cells. TMC had low dark toxicity in the range of concentrations used in the 
A

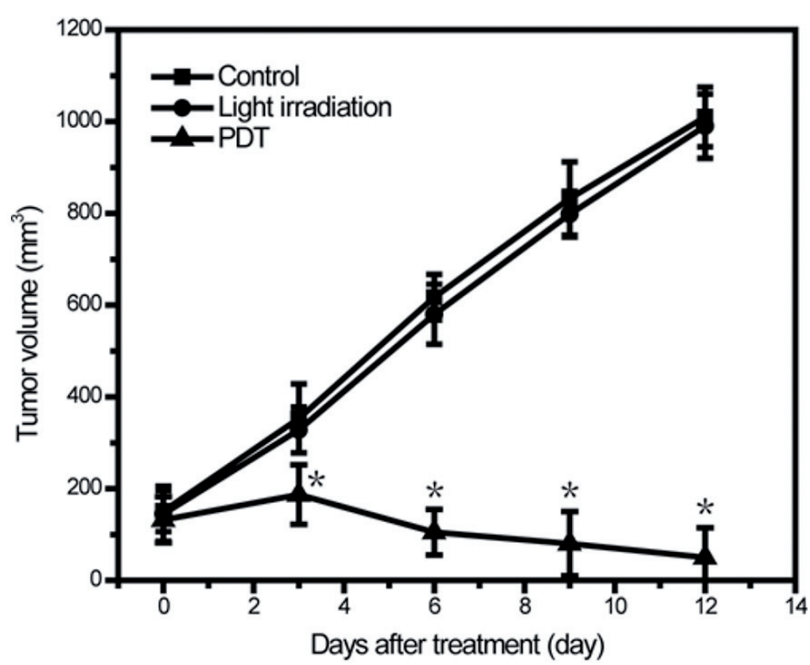

B

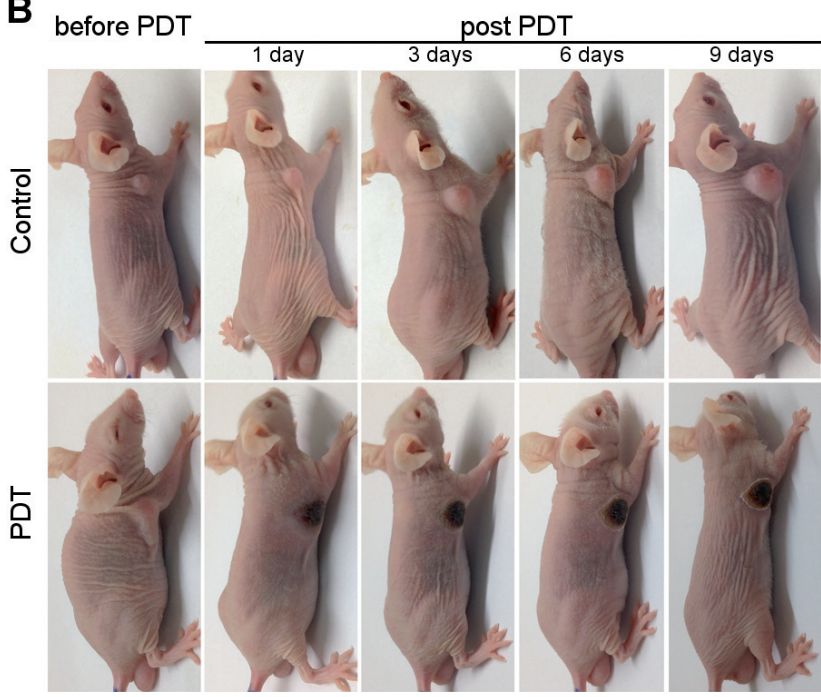

Figure 6. PDT efficacy of TMC in Eca-109 tumor-bearing BABL/c nude mice. A. Tumor volume at different time points after treatment. The control group was untreated. The light irradiation group was treated with light only. The PDT group was treated with light $\left(650 \mathrm{~nm}, 100 \mathrm{~J} / \mathrm{cm}^{2}\right)$ and TMC $(5 \mathrm{mg} / \mathrm{kg})$. All data represent mean $\pm \mathrm{SD}(\mathrm{n}=5)$. ${ }^{*}$ indicates difference at the $p<0.01$ significance level. $B$. Images of mice bearing Eca- 109 tumor before and after treatment (Light irradiation group was not given.).

current study. When treated with $650 \mathrm{~nm}$ light irradiation, TMC showed a substantial cytotoxic effect on the cultured Eca-109 and Hela cells and the cell viabilities showed significant concentration and light dose dependence. The subcellular localization of PS is important for its activity. Some PSs show a broad distribution, while some may localize more specifically. A recent review indicated that intracellular distribution of several porphycene derivatives is heterogenous (lysosomes, mitochondria, ER, Golgi apparatus, among others) [22]. We found that TMC was mainly distributed in cytoplasm and nuclear membranes, to a less degree in cell nuclei, which should represent the preferential target of the photosensitized process.
PDT efficacy is determined by the selectivity of PS accumulation and distribution in the tumor and the surrounding tissue. TMC exhibited some selectivity in tumor and can be almost discharged from all tissues within $24 \mathrm{~h}$ after administration. The largest accumulation of TMC was found to occur in the liver, which is in agreement with the known tendency of most PSs in clinical use. The lack of appreciable TMC accumulation took place at the level of the brain. This observation is in agreement with the known inability of such compounds to cross the blood-brain barrier [23].

In vivo, TMC-PDT showed excellent therapeutic effect in an Eca-109 tumor model. Tumors in TMC-PDT group were significantly inhibited $(\mathrm{p}<0.01)$, while the tumors in control and light irradiation group displayed a fairly rapid tumor growth during all time intervals. PDT can inhibit the growth of tumor by direct damage on cancer cells [24], on the tumor vasculature [25, 26], and by causing immune response [27, 28]. Any of these routes could be responsible for the effectiveness of TMC-PDT in vivo.

In a word, the new chlorin derivative 5,10,15,20-tetrakis[(5$\mathrm{N}$-morpholino)pentyl] chlorine (TMC) was evaluated as a potential PS for photodynamic therapy of cancer in vitro and in vivo. TMC showed strong absorption at $644 \mathrm{~nm}$ and singlet oxygen quantum yield of 0.41. TMC was localized primarily in the cytoplasm and nuclear membranes in Eca-109 cells. In addition, TMC exhibited low dark toxicity and high phototoxicity against Eca-109 and Hela cells. The significant antitumor effect in Eca-109 tumor-bearing mice was achieved with TMC-PDT. The above results reveal that TMC is an effective antitumor candidate for PDT.

Acknowledgments: This work was supported by Chinese National Natural Science Foundation (No. 21372042, 21402236, 81101298, 81301878), Foundation of Shanghai government (No. 14431906200, 14140903500, 13431900700, 13430722300, 13ZR1441000, 13ZR1440900, 14ZR1439800, 14ZR1439900, 15ZR1439900, 15XD1523400, 14SJGGYY08, 201370), International Cooperation Foundation of China and Croatia (6-11) and Foundation of Yiwu Science and Technology Bureau (No. 2012-G3-02, 2013-G3-03).

\section{References}

[1] ST DENIS TG, HAMBLIN MR Synthesis, bioanalysis and biodistribution of photosensitizer conjugates for photodynamic therapy. Bioanalysis 2013; 5: 1099-1114. http://dx.doi. org/10.4155/bio.13.37

[2] ASANO R, NAGAMI A, FUKUMOTO Y, MIURA K, YAZAMA F, et al. Synthesis and biological evaluation of new BSH-conjugated chlorin derivatives as agents for both photodynamic therapy and boron neutron capture therapy of cancer. J Photoch Photobio B 2014; 140: 140-149. http:// dx.doi.org/10.1016/j.jphotobiol.2014.07.008

[3] DOUGHERTY TJ, LAWRENCE G, KAUFMAN JH, BOYLE $\mathrm{D}$, WEISHAUPT KR, et al. Photoradiation in the treatment of recurrent breast carcinoma. Journal of the National Cancer Institute 1979; 62: 231-237. 
[4] ALI H, VAN LIER JE Metal complexes as photo- and radiosensitizers. Chem Rev 1999; 99: 2379-2450. http://dx.doi. org/10.1021/cr980439y

[5] NYMAN ES, HYNNINEN PH Research advances in the use of tetrapyrrolic photosensitizers for photodynamic therapy. J Photoch Photobio B 2004; 73: 1-28. http://dx.doi. org/10.1016/j.jphotobiol.2003.10.002

[6] ASANO R, NAGAMI A, FUKUMOTO Y, YAZAMA F, ITO $\mathrm{H}$, et al. Synthesis and biological evaluation of new chlorin derivatives as potential photosensitizers for photodynamic therapy. Bioorgan Med Chem 2013; 21: 2298-2304. http:// dx.doi.org/10.1016/j.bmc.2013.02.005

[7] DABROWSKI JM, KRZYKAWSKA M, ARNAUT LG, PEREIRA MM, MONTEIRO CJ, et al. Tissue uptake study and photodynamic therapy of melanoma-bearing mice with a nontoxic, effective chlorin. ChemMedChem 2011; 6: 1715-1726. http://dx.doi.org/10.1002/cmdc.201100186

[8] WAWRZNSKA M, KALAS W, BIALY D, ZIOLO E, ARKOWSKI J, et al. In Vitro Photodynamic Therapy with Chlorin e6 Leads to Apoptosis of Human Vascular Smooth Muscle Cells. Arch Immunol Ther Ex 2010; 58: 67-75. http:// dx.doi.org/10.1007/s00005-009-0054-5

[9] ZHANG LJ, BIAN J, BAO LL, CHEN HF, YAN YJ, et al. Photosensitizing effectiveness of a novel chlorin-based photosensitizer for photodynamic therapy in vitro and in vivo. J Cancer Res Clin Oncol 2014; 140: 1527-1536. http://dx.doi. org/10.1007/s00432-014-1717-0

[10] HAMBLIN MR, MILLER JL, RIZVI I, ORTEL B, MAYTIN EV, et al. Pegylation of a chlorin(e6) polymer conjugate increases tumor targeting of photosensitizer. Cancer Res 2001; 61: 7155-7162.

[11] ZORLU Y, DUMOULIN F, DURMUS M, AHSEN V Comparative studies of photophysical and photochemical properties of solketal substituted platinum(II) and zinc(II) phthalocyanine sets. Tetrahedron 2010; 66: 3248-3258. http://dx.doi. org/10.1016/j.tet.2010.02.079

[12] SZEIMIES RM, MORTON CA, SIDOROFF A, BRAATHEN LR Photodynamic therapy for non-melanoma skin cancer. Acta Derm-Venereol 2005; 85: 483-490.

[13] CHENG Y, SAMIA AC, MEYERS JD, PANAGOPOULOS I, FEI BW, et al. Highly efficient drug delivery with gold nanoparticle vectors for in vivo photodynamic therapy of cancer. Journal of the American Chemical Society 2008; 130: 10643-10647. http://dx.doi.org/10.1021/ja801631c

[14] REDMOND RW, GAMLIN JN A compilation of singlet oxygen yields from biologically relevant molecules. Photochemistry and Photobiology 1999; 70: 391-475. http://dx.doi. org/10.1562/0031-8655(1999)070<0391:ACOSOY >2.3.CO;2

[15] VELLONEN KS, HONKAKOSKI P, URTTI A Substrates and inhibitors of efflux proteins interfere with the MTT assay in cells and may lead to underestimation of drug toxicity. Eur J Pharm Sci 2004; 23: 181-188. http://dx.doi.org/10.1016/j. ejps.2004.07.006

[16] NAKAMURA M, FUJINO Y, MOCHIZUKI M, MINODA K, MASUDA K In vivo effects of Prostaglandins on Human Retinoblastoma Cells in Nude-Mice. Jpn J Ophthalmol 1987; 31: 608-620.
[17] OCHSNER M Photophysical and photobiological processes in the photodynamic therapy of tumours. J Photoch Photobio B 1997; 39: 1-18. http://dx.doi.org/10.1016/S1011-1344(96)07428-3

[18] ZHANG JL, DENG L, YAO JZ, GU P, YANG F, et al. Synthesis and photobiological study of a novel chlorin photosensitizer BCPD-18MA for photodynamic therapy. Bioorgan Med Chem 2011; 19: 5520-5528. http://dx.doi.org/10.1016/j. bmc.2011.07.041

[19] YAN YJ, ZHENG MZ, CHEN ZL, YU XH, YANG XX, et al. Studies on preparation and photodynamic mechanism of chlorin P6-13,15-N-(cyclohexyl)cycloimide (Chlorin-H) and its antitumor effect for photodynamic therapy in vitro and in vivo. Bioorgan Med Chem 2010; 18: 6282-6291. http://dx.doi. org/10.1016/j.bmc.2010.07.027

[20] SILVA EFF, SERPA C, DABROWSKI JM, MONTEIRO CJP, FORMOSINHO SJ, et al. Mechanisms of Singlet-Oxygen and Superoxide-Ion Generation by Porphyrins and Bacteriochlorins and their Implications in Photodynamic Therapy. Chem-Eur J 2010; 16: 9273-9286. http://dx.doi.org/10.1002/ chem.201000111

[21] ASHEN-GARRY D, SELKE M Singlet Oxygen Generation by Cyclometalated Complexes and Applications. Photochemistry and Photobiology 2014; 90: 257-274. http://dx.doi. org/10.1111/php.12211

[22] STOCKERT JC, CANETE M, JUARRANZ A, VILLANUEVA A, HOROBIN RW, et al. Porphycenes: Facts and prospects in photodynamic therapy of cancer. Curr Med Chem 2007; 14: 997-1026. http://dx.doi. org/10.2174/092986707780362934

[23] HAO E, FRISO E, MIOTTO G, JORI G, SONCIN M, et al. Synthesis and biological investigations of tetrakis(pcarboranylthio-tetrafluorophenyl)chlorin (TPFC). Organic \& Biomolecular Chemistry 2008; 6: 3732-3740. http://dx.doi. org/10.1039/b807836j

[24] OLEINICK NL, MORRIS RL, BELICHENKO I The role of apoptosis in response to photodynamic therapy: what, where, why, and how. Photochemical \& photobiological sciences: Official journal of the European Photochemistry Association and the European Society for Photobiology 2002; 1: 1-21. http:// dx.doi.org/10.1039/b108586g

[25] KRAMMER B Vascular effects of photodynamic therapy. Anticancer research 2001; 21: 4271-4277.

[26] DOLMANS DE, KADAMBI A, HILL JS, WATERS CA, ROBINSON BC, et al. Vascular accumulation of a novel photosensitizer, MV6401, causes selective thrombosis in tumor vessels after photodynamic therapy. Cancer research 2002; 62: 2151-2156.

[27] KORBELIK M Induction of tumor immunity by photodynamic therapy. Journal of clinical laser medicine \& surgery 1996; 14: 329-334.

[28] CANTI G, DE SIMONE A, KORBELIK M Photodynamic therapy and the immune system in experimental oncology. Photochemical \& photobiological sciences : Official journal of the European Photochemistry Association and the European Society for Photobiology 2002; 1: 79-80. http://dx.doi. org/10.1039/b109007k 